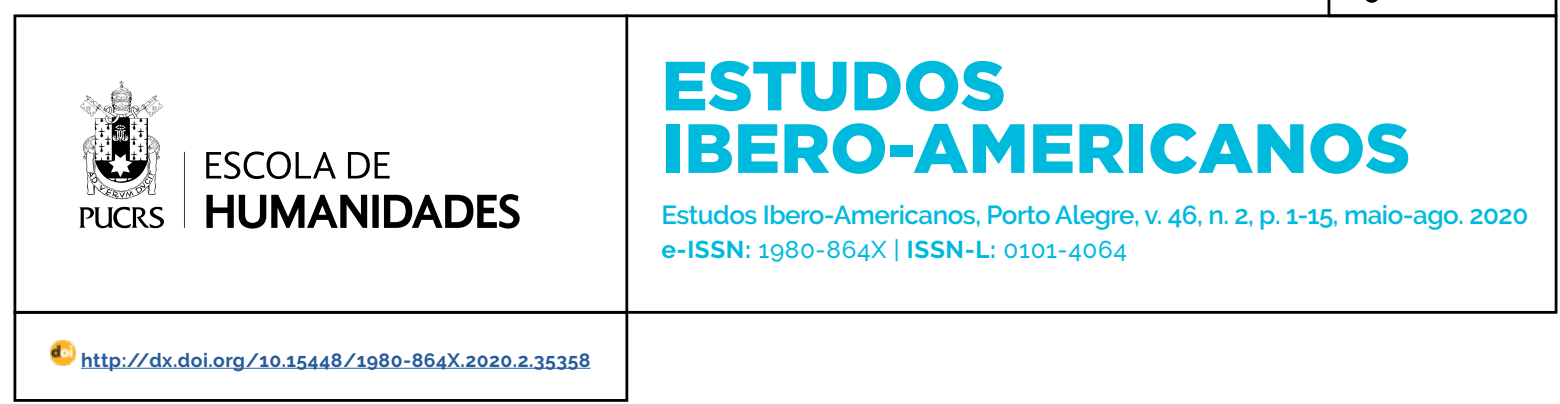

\title{
NEWSBOYS: SPANISH AMERICAN PATRIOT CHILDREN AND 'THE HAZELWOOD MAGAZINE' IN BIRMINGHAM, ENGLAND, 1820s
}

\author{
NEWSBOYS: CRIANÇAS PATRIOTAS AMERICANAS ESPANHOLAS E "A REVISTA \\ HAZELWOOD" EM BIRMINGHAM, INGLATERRA, $1820 \mathrm{~S}$ \\ NEWSBOYS: NIÑOS PATRIÓTICOS HISPANOAMERICANOS Y"LA REVISTA \\ HAZELWOOD" EN BIRMINGHAM, INGLATERRA, 1820S
}

Karen Racine ${ }^{1}$

orcid.org/0000-0001-8879-2927

kracine@uoguelph.ca

Recebido em: 14 set. 2019.

Aprovado em: 16 mar. 2020

Publicado em: 25 ago. 2020.
Abstract: There was a close connection between the expansion of the press and experiments with new pedagogical strategies in the early industrial age. An expanding public school system required textbooks thus creating a whole new category of demand which appealed to printers who always on the lookout for reliable markets. At the same time, literacy was increasingly understood to be a desirable characteristic for a productive, patriotic citizenry. For a period of five years or so in the 1820s, several sons of important Spanish American patriot leaders were sent abroad to study in a progressive school called Hazelwood, near Birmingham in the heart of industrializing England. While there, the boys and their friends wrote and published a monthly periodical called the Hazelwood Magazine that clearly imitated the contents of professional newspapers and shared the underlying values of the medium.

Keywords: Hazelwood school; Spanish American independence; Birmingham; history of childhood and youth; patriotism; Jeremy Bentham; Vicente Rocafuerte; Bernardino Rivadavia; Matthew Hill; press

Resumo: No inicio da época industrial, havia uma forte ligação entre a expansão da imprensa e experienças com novas estratégias pedagógicas. A expansão do sistema escolar público exigiu livros didácticos, criando uma via de exploração completamente nova para a Imprensa que mantinha um olho em busca de mercados fidedignos. Ao mesmo tempo, a alphabetização era cada vez mais reconhecida como uma característica desejável para cidadãos patrióticos e produtivos. Durante apróximadamente 5 anos, na década de 1820, muitos filhos de importantes líderes patrióticos Espanho-Americanos foram enviados para o estrangeiro a fim de estudar numa escola progressiva chamada Hazelwood, perto de Birmingham no coração da Inglaterra industrial. Enquanto lá, os rapazes e os seus amigos escreveram e publicaram um periódico mensal entitulado Hazelwood Magazine que manifestamente imitava o conteúdo de jornais profissionais e compartilhava dos mesmos valores.

Palavras-chave: Hazelwood school; independência espanhola-americana; Birmingham; história da infância e juventude; patriotismo; Jeremias Bentham; Vicente Rocafuerte; Bernardino Rivadavia; Matthew Hill; a imprensa

Resumen: Hubo una estrecha conexión entre la expansión de la prensa y los experimentos con nuevas estrategias pedagógicas en el siglo XIX. Un sistema escolar público en expansión requeria libros de texto que crearan una categoría de demanda completamente nueva que atrajera a los impresores que siempre buscan mercados confiables. Al mismo tiempo, la alfabetización se entendia cada vez más como una caracteristica deseable para una ciudadanía productiva y patriótica. Durante un periodo de aproximadamente cinco años en la década de 1820 , varios hijos de importantes lideres patriotas hispanoamericanos fueron enviados al extranjero para estudiar en una escuela progresista llamado Hazelwood, cerca de Birmingham, en el corazón de la industrialización de Inglaterra. Mientras estaban
Artigo está licenciado sob forma de uma licença Creative Commons Atribuição 4.0 Internacional. 
allí, los niños y sus amigos escribieron y publicaron un periódico mensual llamado Hazelwood Magazine que imitaba claramente el contenido de los periódicos profesionales y compartía los valores subyacentes del medio. Palabras clave: Escuela Hazelwood; independencia hispanoamericana; Birmingham; historia dela infancia y la juventud; patriotismo; Jeremías Bentham; Vicente Rocafuerte; Bernardino Rivadavia; Matthew Hill; la prensa

Hear ye! Hear ye! Read all about it! There was a close connection between the expansion of the press and experiments with new pedagogical strategies in the early industrial age. On a very basic and material level, an expanding public school system required textbooks thus creating a whole new category of demand which appealed to printers who always on the lookout for reliable markets. At the same time, literacy was increasingly understood to be a desirable characteristic for a productive, patriotic citizenry. Recent studies of the transatlantic book market, transnational publishing houses, and the creation of public school systems in Great Britain and across Spanish America in the 1820s have demonstrated clearly that all these phenomena are connected. The first generation of Spanish American patriot children began their studies during that tumultuous decade and then carried those early lessons with them into adulthood as they took up various roles in the consolidation of the republican state. Many of their personal habits, practices and intellectual models were formed while in residence abroad and then later adapted into local settings when they were back home. In school, they learned to divide their daily activities into regular timed segments, to compete for recognition and material rewards, and to recognize usefulness as a primal virtue. By reading newspapers, the youths' mentality was formed in a print context that foregrounded commercial announcements and official activities - both political and military - as the things that were considered to be newsworthy. Periodicals and newspapers also framed stories according to separate and distinct categories of national and international news and thereby conditioned their readers to function in a constant state of global information flow. The early nineteenth century was, indeed, an era during which books, classrooms, and newspapers "helped to shape the ideological consciousness of the middle class" (HIGGINS, 2005, p. 1).

For a period of five years or so in the 1820 , several sons of important Spanish American patriot leaders were sent abroad to study in a progressive school called Hazelwood, near Birmingham in the heart of industrializing England (RACINE, 2010). While there, the boys and their friends wrote and published a monthly periodical called the Hazelwood Magazine that clearly imitated the contents of professional newspapers and shared the underlying values of the medium. As a genre, the serial publication combines elements of immediacy and contemporaneity with a sense of ongoing dialogue and conversation (STEWART, 2008, p. 25). In that sense, editors of a periodical had a dynamic opportunity both to comment on events and, in turn, to be commented upon. They engaged in collective taste-making during a time in which public opinion was becoming a crucial component of political legitimacy (BANTMAN and DA SILVA eds, 2018; DA SILVA and ABREU, eds., 2016; ROLDÁN VERA and CARUSO, eds., 2007; ROLDÁN VERA, 2003); LUSTOSA, 2000). The genre of the periodical monthly magazine was perfect for the Hazelwood boys' technical and intellectual abilities and their evolving patriotic self-image. Like the adults they admired, the youths "cultivated a style which offered both the cachet of a gentlemanly education, and the informality and entertainment of an intimate address" (NORTH, 2009, p. 158). The newsboys of the Hazelwood Magazine adapted many of the same practices of professional periodical press: articles were unsigned, collaboration was expected, and knowledge was divided into distinct sections which included: book notices and reviews, school news, humorous anecdotes, and literary productions, all peppered with a strong dose of liberal patriotism.

Hazelwood School was one of the many progressive social experiments that emerged in England in the 1810 s and 1820 s, alongside things like Robert Owen's socialist labour cooperative community called New Lanark, and Elizabeth Fry's tireless campaigns for prison reform. Hazelwood 
was founded by Thomas Wright Hill, an English eccentric who had an interest in science and who had been an associate of the famous chemist Dr Joseph Priestley. Four of his sons went on to contribute mightily to national social causes beyond the sphere of childhood development. Matthew Davenport Hill was the Recorder for Birmingham and an MP for Hull who took a particular interest in penal reform. Frederic Hill was His Majesty's Inspector of Prisons who tried to put humanitarian recommendations for the treatment of inmates into practice. Rowland Hill was the inventor of the penny postage stamp, a democratic innovation which allowed senders to pay for their own letters and parcels in advance rather than requiring an unexpected fee to be paid by the recipient. And Arthur Hill was a mechanic who popularized his brother's new postal service on an industrial scale through the invention of envelope franking and folding machines (BARTRIP, 1980, p. 57n). One scholar has described them as "middle-class, utilitarians, and heretics" (GOOD, 1945, p. 117). Rowland Hill, though, preferred to characterize his family in a more radical vein, proudly describing them as Englishmen "born to a burning hatred of tyranny" (DOBSON, 1959, p. 268).

Thomas Wright Hill founded his first school in 1803, a small enterprise called Hill Top in Birmingham. The second generation took over its operation in July 1819, relocated to a new, purpose-built hall, and renamed it Hazelwood School. Throughout the 1820s, the institution flourished under the patronage of utilitarian philosopher Jeremy Bentham and his activistwriter friend John Bowring. Eventually, the school's student demographic included not just the sons of progressive local industrialists, but the children of prominent political orators like Leigh Hunt, and talented Catholic boys whose religion barred them from entry into public schools and universities. Beginning in 1824, several Spanish and Spanish American boys took up residence at Hazelwood, including: Antonio Rodríguez, Bernardino and Joaquín Rivadavia, Luis Castro, Gregorio de Molina, Vicente and Juan Rocafuerte, Pedro Pico, Pedro Álvarez, Miguel Valencia, José Castro, Mliguel] Echeverría, Manuel Monasterio, Nlicolás] Rodríguez Peña, two unidentified South Americans, and another Spanish boy. There were no Brazilians or Portuguese boys at the school, although there were representatives of liberal patriotic movements elsewhere, including several Irish children, and at least three Greeks: Eustratios Rallis, the son of a Thessaloniki merchant, Stamos Nakos, the son of the Governor of Livadia province loannis Nakos, and George Tombazis, a teenager likely related to lakovos Tombazis, the first Admiral of the independent Greek navy.

Hazelwood School was owned and operated by the entire Hill family, but Matthew Davenport Hill and Rowland Hill were its most active directors. Their iteration was more self-consciously experimental, systematic, and was imbued with progressive ideals than its predecessor Hill Top School had been. Hazelwood's pedagogy was based on the monitorial method - sometimes called the Lancaster or Bell system - in which older students would be engaged in the training of the younger ones, and which preferred direct learning through experience and discovery to older, more traditional practices of rote memorization and recitation. Matthew Hill described their guiding philosophy as being based on the belief that "[a] school should not necessarily depart from the model of real life." They thought that curriculum should be "as interesting as possible" with an emphasis on candor, that teachers should be willing to entertain any and all questions a student might have, and that the boys would be allowed to follow their own interests wherever possible (HILL, 1825, pp. 75, 96, 136-37). For this reason, Hazelwood school operated as a microcosm of society itself. They boys staffed their own courts (with judges, prosecutors and defense attorney roles), they controlled and voted on a significant

\footnotetext{
2 The Greek boys were part of a contingent being sponsored by Edward Blaquiere, John Bowring. The Greek Committee and Bentham. See Panyotis Rodios' letter on behalf of the provisional Government of Greece to Bentham, (Napoli de Romana, 12 August 1824 ) in O'SULLIVAN and FULLER, eds. 2006. XII: 24-25.
} 
portion of the school's discretionary budget for books and scientific equipment, and they sat on several committees, including one that monitored their charitable donations. It was good practice for the work the Spanish American boys imagined they would be doing when the went home to build their newly independent nations.

One of the most important components of the Hazelwood experiment was the publication of a school newspaper, the Hazelwood Magazine, written, printed, published and distributed entirely by the boys themselves. It was a surprisingly professional and widely distributed production for its time (CURRY, 1977, p. 12n). ${ }^{3}$ Hazelwood Magazine sold for four pence per issue and consistently made a profit. It had more than sixty regular subscribers, including Bentham, Bowring, and free speech activist William Hone. This publishing venture proved to be so successful that Rowland Hill even had plans to teach his boys the skill of engraving with a view to adding lithographic capability to their production. Unfortunately, funds did not materialize and the idea never came to fruition (DOBSON, 1960, p. 7). Hazelwood Magazine has a professional tone, with interests and section titles that mimicked those of the major urban commercial newspapers: Foreign Intelligence, Domestic Occurrences, Literature, Minutes of the School Committee, New Additions to the Library, notices of trials resulting in disciplinary action, and humorous anecdotes. The creation of an in-house press was directly related to the school's pedagogical mission of training the boys to be active and engaged citizens. As Matthew Hill explained in his book, all the school's activities were built around the idea of "a constant motive for mutual examination, and a constant feeling of mutual responsibility." Childhood was the best time to build habits of truth-seeking and critical thinking because, as he said, "much later in life the mind starts revolting against things it does not already know" (HILL, 1825, pp. 182-183, 213).

The students' experiment with their press began in the school year 1822-1823 and they continued to publish monthly until 1831. From the beginning, the magazine, like the school itself, enjoyed the patronage of Jeremy Bentham, who was also involved in the Westminster Review and was writing various constitutional draft projects for Iberian and Southern European countries at the same time. He took a great interest in the boys' activities. Thomas Wright Hill wrote to Bentham in March 1824 saying that "the Editor of the Hazelwood Magazine will acknowledge your kindness to himself and to us through him." (HILL to Bentham, 8 March 1824). The first issue proudly introduced itself as being "Printed and published by the Pupils of Hazelwood School, Birmingham." The boys acknowledged that earlier classes had discontinued their previous publishing effort, the Hill-Top Chronicler because of the difficulty of the cumbersome process of manually printing each copy. The Hill family, however, had acquired a modern steam-powered printing press and gave it to the boys for their use (Hazelwood Magazine. v. 1. n. 1. September 1822, p. 1). It was part of their constant emphasis on usefulness. As the utilitarian headmasters believed, "the use of writing is to be read" (HILL, 1825, p. 274).

The first issue of the Hazelwood Magazine opened with two classical epigrams which was a common strategy used in the periodical genre to signal one's academic accomplishments and cultural cosmopolitanism. The boys were speaking the layered language of the educated middle classes by using elite references to legitimize their entry into the broader public print sphere. From Virgil's Aeneid, the boys selected their motto: "Audite O! Mentibus aequis / Neve haec nostris spectentur ab annis/Quae ferimus", which means "Listen with unbiased minds; nor be these overtures we bring be judged of by our years" (VIRGIL, Aeneid, Book IX, lines 234-236). With these words echoing down from the ages, the boys signalled their commitment to free expression and the desire to search for truth. They took their second motto from Horace: "Aetatis cujusque notandi sunt tibi mores", or "You must Mark well the Manners of every Age" (HORACE,

\footnotetext{
3 Monthly circulations of some of the major periodicals at the time were The Monthly Magazine - 3000-4000; The Examiner - 2200; The Edinburgh Annual Register - 2000.
} 
Ars Poetica, line 156). ${ }^{4}$ Both selections clearly emphasized the boys' confidence that they had something important to say and, despite their age, the means and the right to say it.

\section{Books Purchased and the Hazelwood Library}

One of the key features of British periodicals in the 1820 s was a very visible emphasis on reading, readership, and the creation of markets for print media. The front pages of daily newspapers were entirely taken up with commercial notices, many of which were for recently published books or offering places at newly-opened schools. Similarly, the genre of the book review dominated serial magazines; the Edinburgh Review and the Quarterly Review were the most important venues during the 1820 s but there were many others. One scholar has described the journal as "the paramount medium ... of the 1820s" and identified several editorial lines, ranging from the liberal Westminster Review, the trend-setting Athanæum, and the "foreignizing" European Review, Foreign Review, and Foreign Quarterly Review (SAGLIA, 2002, p. 50). The boy editors of the Hazelwood Magazine reflected this cultural concern with literacy by replicating the content categories of adult magazines and newspapers. Nearly every single issue printed a notice about books purchased for, or donated to, their library, often with anonymous commentary on the subject. Hazelwood School had a surprisingly large collection of books available to its young students. By 1825 , the library already boasted 700-800 volumes in several languages, representing many different fields of knowledge (HILL, 1825, p. 163).

Because of the Hills' close connection to Jeremy Bentham and his utilitarian circle, the books purchased and discussed in Hazelwood Magazine tended to reflect the literature of usefulness. In many ways, the newsboys' editorial line echoed that of the Westminster Review, a Benthamite magazine for philosophical radicals founded in 1824. The Westminster Review opposed aristocratic privilege, incorporated a global vision based utilitarian economics, and "relentlessly advocated the abolition of trade restrictions in Britain and the rest of the world" (TODD, 2008, p. 376; FETTER, 1962, p. 570; LLORENS, 1951, p. 126). Contributors included: James Mill, John Stuart Mill, Henry Brougham, John Cam Hobhouse, Henry Southern, Harriet Martineau, Ugo Foscolo, and Antonio Alcalá Galiano. Indeed, many of the authors who wrote for the Westminster Review also visited Hazelwood School and there was a definite overlap between their books and reviews and the sorts of things about which the boy editors took notice.

In September 1823, new additions to the Hazelwood library included: a handsome edition of Shakespeare, Gibbons' Decline and Fall of the Roman Empire, Mollien's Travels in Africa, Maximilian's Travels in Brazil, Ivanhoe, Peveril of the Peak, and The Pirate. In February 1824, the boys announced their committee had purchased Buckingham's Travels in Palestine, issue \#1 of Oriental Herald, Zimmerman's work on Solitude, Green's Chronological History of the Reign of George III, Blagdon's Dictionary of Quotations, the Government and Manners of Ancient Greece, Sketches of the Manners and Institutions of the Romans, several novels by Maria Edgeworth, including: Tales of the Fashionable Life, Belinda, and Patronage, and all of works by Sir Walter Scott that they did not already have on their shelves. In 1825, Edward Lewin of the School Fund committee authorized additional purchases of the Oriental Herald, the European Magazine, The Mirror, Lessing's Fables and Epigrams, Basil Hall's Voyage to Loo Choo, the History of Brabant, and a copy of the constitution of Guernsey (BRUCE CASTLE ARCHIVE, Hill Family Manuscripts). Leigh Hunt donated a copy of Thomas Landseer's famous work on quadrupeds, which contained exciting engravings of animals from around the world that were linked taxonomically and assigned regional identities: Andean alpacas and llamas, Egyptian camels, Canadian bison, the Asian orangutan, Australian emus, and British wolves and foxes. In

4 The rest of the line reads: "and assign their proper Beauty and decorum to Men's varying Temper and Years." 
1826 the newsboys announced the acquisition of Robert Henry's 12-volume History of Britain from the First Invasion, Thomas Bewick's Natural History, Charles Rollin's Ancient History, a history of the revolutions in France, editions of Shakespeare and Molière, and numerous travel accounts. They also bought and reviewed Thomas Hope's Costumes of the Ancient Greeks and Romans, which elevated the pride of the resident Greek students and directly linked the glorious past with the newsworthy present. In 1827 the boys bought John Ayrton Paris' popular new book called Philosophy in Sport made Science in Earnest, and Turner's history of the Middle Ages.

A quick glance through the book purchases and announcements published by the newsboys in the Hazelwood Magazine reveals both their close attention to the form and content of professional periodicals and their absorption of a cosmopolitan, liberal world view. Royal Navy Captain Basil Hall gave them a copy of his book Notice on the Climate of the Western Coast of South America and Mexico which allowed the South American boys to show readers that scientific contributions emanated from their part of the world too. The Hazelwood book announcements reflected their interest in liberal revolutionary movements everywhere - a global political project in which their own family members were active participants and which allowed the boys to imagine themselves as advancing too. They publicized books like Henry Holland's travels in Greece, Edward Blaquiere's History of the Greek Revolution, Thomas Edward Bowdich's Mission to Ashantee, William Alexander's watercolors of ancient Chinese costumes, and the memoirs of Spanish liberal exile General Francisco Espoz y Mina. In just five years, the Hazelwood library had grown to more than 800 volumes, most of which reflected the boys' commitment to the ideal of useful education, effective governance and the desire for a comprehensive, global awareness of the state of civilization.

\section{Domestic Occurrences, Humorous} Anecdotes, and Fashionable Arrivals

This section of newspaper was something that was peculiarly English, an often-remarked-upon oddity of their culture that foreigner observers considered to be an example of the "national appetite for tittle-tattle" and gossip. European readers could not understand their British counterparts' insatiable interest in frivolities like parties and fancy balls, the announcements comings and goings of notable people, descriptions of the newest fashions etc. (LANGFORD, 2000, p. 94). Most daily newspapers in Britain also had a column that listed births, deaths, marriages, and military promotions (CALEDONIAN MERCURY. $\mathrm{n}$. 16309. 6 March 1826). The Morning Post offered its readers a recurring feature called "Fashionable Changes" which tracked the movements of the royals, aristocrats, wealthy business families and foreign diplomats, including some of the parents and guardians of the Spanish American and Greek boys enrolled at Hazelwood (THE MORNING POST. n.17122. 4 November 1825). The Morning Chronicle, a daily newspaper that had a close, collaborative relationship with Spanish American patriots in London, had a similar regular feature called "The Mirror of Fashion" in which it described for readers events such as royal levees, aristocratic dinner parties, and the fashionable set's seasonal visits to their city houses and country estates (THE MORNING CHRONICLE. n. 17660. 20 April 1826). The Morning Chronicle is a particularly relevant model because it regularly printed stories on behalf of Spanish American patriot governments and its articles were frequently reprinted in their liberal press back home (ALONSO PIÑEIRO, 2004, p. 30). ${ }^{5}$

Some of the domestic occurrences reported in professional newspapers were intended to educate their readers by recounting a cautionary tale. One typical example reported a straightforward news event, the death of the Duke of Kent who had caught a cold while out walking in the rain. It seems, though, that he ignored doctor's advice and, as the article warned, "[i]n the morning, the

\footnotetext{
5 See, for example, the Morning Chronicle's article on freedom of the press which was reprinted verbatim in Buenos Aires' El Centinela. Sunday, 16 March 1823.
} 
symptoms of fever were increased, and though His Royal Highness lost 120 ounces of blood from the arms and by cupping, he departed from this life, as we have stated, at 10 o'clock on Sunday at forenoon" (MORNING CHRONICLE. 25 January 1820). The newsboys of the Hazelwood Magazine adopted the same practice and used their newspaper to educate their peers about the importance of caution and attention. For example, they reported that a fellow student had fallen off a swing while playing recklessly and died a few days later; the editors were very sad and expressed their "hope [that] this will be a lasting caution to those who are in the habit of exposing themselves to unnecessary danger" (HAZELWOOD MAGAZINE. v. 1, n. 12. October 1823, pp. 6-8).

Another regular feature of British newspapers and magazines was the insertion of anecdotes and humorous episodes, some of which carried a moral message and were probably apocryphal, but many others which had no newsworthy function except the desire to entertain. The Hazelwood Magazine newsboys delighted in publicizing their pranks and witticisms just as much as adults did. One issue repeated the joke that a newly arrived student mistranslated a Latin passage about the Battle of Marathon that read sub montis radicubus as "under a mountain of radishes" (HAZELWOOD MAGAZINE. v. 1, n. 7. April 1823, p. 4). In another issue, they used the same format as professional periodicals to issue an alert in all capital letters: "ANECDOTE: During an examination of new scholars on the subject of mythology, the teacher was heard to ask 'which of the gods was the messenger?' And a little boy student passing by replied, 'Louis Lenzi is the messenger this week, Sir' " (HAZELWOOD MAGAZINE. v. 5, n. 6. September 1827, p. 92). The boy editors printed another story about a recent school dance. Apparently one of the foreign schoolfellows had been invited to join in the quadrille but was too shy to try it. They reported: "By way of pleading ignorance of our way of dancing, he answered that '[h]e could not dance English' " (HAZELWOOD MAGAZINE. v. 2, n. 10. December 1824, p. 69). In all three examples, the location of the humor was complicated because it relied both on the clever wordplay of insiders which emanated from the incomplete understanding of outsiders.

Another example combined the humorous anecdote and fashionable arrival categories. The "FASHIONABLE DEPARTURE: On the _- of April, Mr Low Fever took his depart from Hazelwood, where he had for some time taken up residence to the great annoyance of all its inmates." He had been uninvited, incurred the need for extra servants, left dirty laundry and required expensive food. Mr Low Fever had a cousin in the West Indies, Mr Yellow Fever, and a father called Mr Plague from Egypt. "We sincerely hope he will never again be so rude as to intrude upon us his unwelcome and disagreeable company" (HAZELWOOD MAGAZINE. v. 5, n. 3. April 1827. pp. 42-43; HAZELWOOD MAGAZINE. v. 5, n. 4. May 1827, p. 45). In other instances, however, a more sincere notice of departures was taken, such as the farewell given to an unidentified popular student who graduated in June 1827; he had worked hard, corrected his bad habits and earned the right to have his name engraved on the Tablet of Honor. When the Ecuadorean Vicente Rocafuerte left for his midterm holidays, he published an emotional farewell in which he found it impossible for his pen to describe his feelings about being a Hazelwood boy (HAZELWOOD MAGAZINE. v. 5, n. 7. September 1827, p. 99). A British boy reciprocated in October 1828 with his "Farewell to a Friend on his Departure for a Foreign Land" which contained the sweet lines:

\footnotetext{
Farewell! - Tho' distance intervene

A friend's fond prayer shall still arise

And tho' the ocean roll between

Though are still present to mine eyes.

(HAZELWOOD MAGAZINE. v. 6, n. 8. October 1828, pp. 117-118)
}

The Spanish American newsboys certainly were familiar with the hybrid genre of the sentimental farewell, or despedida, which their own patriotic presses back home had used to praise departures 
made in service to the nation; in Chile, two famous published despedidas honored those men who had joined Jose de San Martin's Army of the Andes (DESPEDIDA, 1820). It is clear that the Spanish American boys counted themselves among those people who had travelled away from home as a form of patriotic service. In the archives of the Argentine Legation to London there is a letter from an Argentine boy named Miguel Valencia who wrote from Hazelwood School on 17 December 1827, explaining to the envoys the importance of his studies to prepare him for future work on behalf of the country, and asking them for more money to sustain him in such an expensive country or else he would have to return home (VALENCIA, 17 December 1827).

As an experimental institution that focused on making boys into useful citizens, Hazelwood School attracted important visitors who came to tour its facilities and talk with the boys. These fashionable arrivals and dinners were documented in the pages of the Hazelwood Magazine and clearly show that the boys were being treated as rational beings worthy of serious conversation. If they were not quite adults yet, at least their schoolwork was considered an ageappropriate form of patriotism. In September 1822, the Tripolitanian Ambassador paid a visit to the school (HAZELWWOOD MAGAZINE. v. 1, n. 1. September 1822, p. 6). At the end of the same month, Marc-Antoine Jullien, who the newsboys described as "the author of valuable works in education and the editor of Revue Encyclopédique" came to see them and left some lines with his autograph (HAZELWOOD MAGAZINE. v. 1. n. 2. October 1822, p. 5). It was like meeting history in the flesh. Jullien had been closely associated with Robespierre, was an active founder of the liberal Neapolitan Republic, and later built a career in publishing and pedagogy. He was friends with the Swiss education reformer Pestalozzi and worked to expand the monitorial method in Europe. Jullien must have been impressed because less than a year later, the boys excitedly printed a notice that "our BROTHER EDITORS of La Revue Encyclopédique" had included an article about them and their press. Jullien wrote approvingly about the Hazelwood style of education in which "the pupils are introduced to forms of administration and governance similar to those that prevail in society", and he particularly singled out "the monthly newspaper. The editors are the students themselves who insert news of interest to the school" and which he thought should be incorporated into the classes of the École Polytecnique "which could extend the salutary influence outside the school."6

In May 1824, Robert Dale Owen, the son of Robert Owen of New Lanark, visited the boys and taught them some gymnastic exercises. In the course of their conversations, Owen told the boys about Philipp Emanuel von Fellenberg's school called Hofwil near Bern in Switzerland which operated along principles of self-governance very similar to their own (albeit with more emphasis on physical activity). The Hazelwood newsboys took careful notes and then wrote about the visit in their newspaper (HAZELWOOD MAGAZINE. v. 2, n. 4. May 1824, p. 29). That same year in August, Edward Masson, a friend of Bentham who was active in the Greek Committee, toured the school as part of his preparation to go to Greece and found his own experimental school (. Thomas Wright Hill mentioned the visit in a letter to Bentham in which he compared this transnational collaboration as "working in mines opened by others" and hoped that "habit can supply the place of zeal" (HILL, 18 August 1824). The Hazelwood boys proudly showed Masson their accomplishments, which they described in their newspaper as "the plans we adopted here" and were grateful when he left them a copy of the first Greek patriot newspaper for their library. Captain Basil Hall "recently returned from his tour of South America, visited the school, presented the boys with a copy of his book... and delivered a lecture on trade winds" which the boys reported to have been clear and comprehensible in their

6 Jullien's comments appear in Revue Encyclopédique v. 53. 1823. p. 538. They are reprinted in Hazelwood Magazine v. 1. n. 12. October 1823, p. 2 
three-page article summarizing Hall's comments (HAZELWOOD MAGAZINE. v. 2, n. 8. October 1824, pp. 53-56). Hall must have been as impressed as Jullien had been two years earlier, because he subsequently sent the newsboys a case of steel pens to use as one of their school awards.

Accounts of visitors to the school reflected the headmasters' liberal inclinations and the pupils' sense of being active participants in social causes of real importance. In December 1825, the school received a visit from the Liverpool businessman James Cropper who was a major figure in the abolitionist movement. He had written several pamphlets in which he attacked the planters' economic arguments for maintaining African, including one that opened with the thundering line "The first step to the removal of an evil, is to prove its existence." In Cropper's opinion, the periodical press had a crucial role to play in abolition because rational people, when presented with clear evidence, cannot deny the correct and moral action (CROPPER, 1823, pp. 3-7). The boys heard him give a lecture on "the present state of slavery in our colonies" and Cropper's plan for complete abolition. In an unsigned editorial, the Hazelwood boys remarked that "[t]his discourse was interesting and many of us made reports on it." Cropper left them with several books on abolition and the history of the slave trade to help them hone their own arguments (HAZELWOOD MAGAZINE. v. 3, n. 10. December 1825, p. 72). Back in Spanish America, the newsboys' parents advocated similar causes and, when they finally achieved control and established republican patriot governments, quickly abolished the slave trade and African slavery in Mexico, Chile, Argentina, and Chile.

\section{Letters to the Editor}

Once each month, the Hazelwood students were required to write a public letter to a friend on a subject of their own choice - which could be done in various languages - and if it was not done on time, the teacher would assign a topic (HILL, Public Education, p. 165). The Hazelwood Magazine printed many of these compositions as letters to the editor, a relatively new genre that was evolving out of a much older and more contrived literaryepistolary form of writing over the course of the early nineteenth century. The newspaper-based "letter to the editor" has been characterized as a democratic extension of the public sphere into the world of print which offered the possibility of regular folk contributing to discussions on important issues of the day (PERRIN, 2016, p. 56). It allowed for the adoption of alternative voices and perspectives, created a space for interaction and participation and, in the context of Hazelwood Magazine, provided the young boys with a public affirmation that their voices were taken seriously by adults. Scholars of modern communications stress that the essential feature of letters to the editor as a serialized genre is the fact that they are intended to build relationships, not just proclaim knowledge authoritatively and uni-directionally (SNYDER and SORENSON, 2018, p. 123).

Of the letters to the editor that appeared in the Hazelwood Magazine, many of them expressed patriotic sentiments related to the independence movements in both Spanish America and Greece. In December 1823, Mark Anthony Buggins wrote to the editors in response to their call for contributors in which he stated publicly "I am, you must know, most violently liberal" and proceeded to decry the state of miners in the country and link it to the recent purge of Spanish liberals by commenting on having seen a passing ship called the "GENERAL MINER", a pun intended to refer to Spanish liberal General Francisco Espoz y Mina who had been involved in several conspiracies against the absolutist monarch Ferdinand VII from his exile in London (HAZELWOOD MAGAZINE. v. 1. n. 14. December 1823, pp. 6-7). Two months later " $X$ " reported having seen a smuggling boat being chased by a revenue cutter in Devonshire during Christmas holidays and provided a report because he "thought readers would be not entirely uninterested" (HAZELWOOD MAGAZINE. v. 2. n. 1. February 1824, pp. 3-4). These letters are very similar in tone and content to ones that appeared in their parents' preferred publishing outlets and their later official policies as government leaders. For example, a pseudonymous writer calling himself 
"Phocion" wrote a letter to the editor of the Morning Chronicle which was titled "Tripolizza, St Domingo and the Slave Trade" and compare French atrocities in Haiti to those of the Turks in Greece (MORNING CHRONICLE. 31 December 1821).

Spanish Americans appear both as writers and subjects of letters to the editor of the Hazelwood Magazine, expressing concern with similar liberal causes. In November 1824, the newsboys printed a letter from "E. C", who identified himself as an old school-fellow now settled at La Guaira in Venezuela. The correspondent reported on matters of interest, noting that the "white to colored population ratio" was 1:12, and that citizens were trying to pass a law that would restrict trade to those who were citizens or who had taken an oath of allegiance to the country. The writer expressed his opinion that " $[t]$ his would never do in a country where all the commerce is in the hands of foreigners; so the English Consul bullied them out of it, and now affairs run smoothly in their usual channel." The second half of the letter was published in the next issue and described a patriotic gathering in which there was breadfruit, beer, banjos, lots of cigars and "not much of what English call society; blacks and white never mix." The former student had taught the local priest "the ART of PUNCH-MAKING" and scoffed at all the cheers of ii Viva libertad!! "as if we were actually as mad as the republicans themselves" (HAZELWOOD MAGAZINE. v. 2. n. 9. November 1824. pp. 61-63; HAZELWOOD MAGAZINE. v. 2, n. 10. December 1824. pp. 67-69). Another letter reported that there were streets still in ruins in both Caracas and Bogotá from the earthquake of 1812, but that Caracas at least, was being rebuilt with long, orderly straight streets on a grid pattern which were being named for patriotic events rather than saints (Calle del Triunfo, Calle de las Leyes Patrias, Calle del Campo de Carabobo etc). The cross-cultural commentary is evident: Walker told his friends back in England that the llaneros "are so besotted as to think that no country in the world is equal in science and civilization as their native plains" (HAZELWOOD MAGAZINE. v. 3, n. 1. February 1825, pp. 5-7; HAZELWOOD MAGAZINE v. 3, n. 2. March 1825. pp. 9-10).
The potential for civil discussion and selfcriticism was also evident in the letters to the editor. In September 1827, someone identified as "An Old Schoolfellow" from Birmingham wrote to the editor to express his opinion that the magazine "is not so well conducted as it was at one time. I feel pretty confident that a great part of the Magazine is composed by yourself." (HAZELWOOD MAGAZINE. v. 5. n. 9. November 1827, pp. 134-139). The person, who obviously had been involved in the print production at some point himself, decried some of the recent changes. Where the magazine had previously been in the hands of a single editor, now it was administered by a committee which had reduced the space for alumni contributions and eliminated the woodcut illustrations. Furthermore, the committee had recently decided to send a copy of the magazine home with each boy at half-year and to charge it to their school bill. The letter to the editor rejected this practice on the grounds that it removed the incentive for quality because the magazine did not have to worry about attracting subscribers. A subsequent news item signed by M. V. [Miguel Valencia] does seem to indicate some internal problems; he had gotten an admission from the Magazine Committee that the previous accountant had gone off and that accounting records had been lost (HAZELWOOD MAGAZINE. v. 5. n. 9. November 1827, p. 125).

\section{Literature and Patriotism}

British newspapers and periodicals of the early nineteenth century typically included sections devoted to literary reviews, with a particular interest in drama and poetry. The Examiner devoted much of its space to the section called "Literary Notices." The mass-market daily newspaper The Morning Post regularly printed items in a column called "Literature." Even a small regional weekly like The Hull Packet and Daily Commercial Advertiser had a recurring feature entitled "The Poet's Corner" (MORNING CHRONICLE. Friday, 31 August 1821).? The pieces they printed were heavily inflected

7 Among the many other examples see: The Examiner. n. 964. 23 July 1826; The Morning Post. n. 17349. 26 July 1826; The Hull Packet and Original Weekly Commercial, Literary and General Advertiser. 15 August 1826. 
with the sort of generic patriotism of the Romantic era that drew heavily on references, imagery and models from the Greek and Roman classics. As Greek patriots fought against the Turks for liberation of their ancient homeland, liberals everywhere could link their shared struggles to the memory of the glorious classical past. Elias Durán de Porras has identified something he calls "It]he battle for information" in the early industrial age. It is also a useful metaphor to describe liberal patriots' habit of wielding their pens as weapons and recruiting the memory of ancient warriors into the service of their own modern cause (DURÁN DE PORRAS, 2008, p. 43). The liberal editors of the Morning Chronicle, for example, published Tacitus's description of the despised Roman emperor Vitellius because they felt that it was "so singularly applicable to the abdication of Napoleon" that they had to quote it "for the gratification of our classical readers" (MORNING CHRONICLE. 31 August 1821). Spanish literature of the Golden Age was another common inspiration. At the Hill's school, The Public Exercises, or public examinations by recitation, for the school year 1824 used a dialogue drama based on the eighteenth-century picaresque tale of Gil Blas, and the results were "Printed by Henry Hopkins, Lewis, and Johnson, at the Hazelwood Press" (UNIVERSITY COLLEGE LONDON).

The Hazelwood newsboys also used this combination of classical references and current events to highlight both their own educational achievements and their ability to connect the classical past with the patriotic present. William Watson published "An Enquiry into the Probability of the Story of Regulus" because of his interest what he described as "the patriotism and selfdevotion of this character." He admired the "Republican Romans, the fidelity of his oath, his regard for his country's welfare, and negligence of his own interest," even though he had to admit the "prima facie improbability of the story." In Watson's political judgement, it was highly unlikely that a nation would send a hostile captive general back to negotiate for peace with his own side; it was much more likely that Regulus had escaped. Watson also published "An Enquiry into the Causes which led to the contests of Gladiators among the
Romans and the effects which they Produced on the minds of the People" and "Grecian Song of Triumph after the Battle of Salamis" (HAZELWOOD MAGAZINE. v. 5. n. 9. November 1827, pp. 128-133; HAZELIWOOD MAGAZINE. v. 6. n. 4. May 1828, pp. 57-59). In September 1828, boy editor Edward Lewin published a copy of an address on the conduct of Marcus Brutus, followed by his own analysis of whether or not the man was justified in joining the conspiracy against Caesar. The Hazelwood Magazine also printed literary homages to several other ancient figures linked to the idea of freedom and self-determination; for example, there was a speech called "Leonidas to his Soldiers Before the Battle of Thermopylae", and also "Hannibal's Answer to the Ambassadors, who carried the Decree, Recalling him to the Defense of Carthage." After the fashion of the day, the editors mined British history for inspiration too, printing an ode to Cassivelaunaus, the ancient British tribal chief who held the line against a Roman invasion in 54 BCE.

The connection between the glorious past and the sure-to-be-equally glorious present was clear and immediate at Hazelwood School because of the demographics and national origins of the children themselves. In 1825, two new Greek students arrived, Eustratios Rallis and Stamos Nakos, who "were so good as to appear on this occasion in the costume of their country" even though their "appearance produced a dead silence" (HAZELWOOD MAGAZINE. v. 3, n. 1. February 1825, p. 5). George Tombazis, who won $3^{\text {rd }}$ general prize in the academic competition of 1829, was identified in the school newspaper as "a Greek native, so particularly meritorious" (HAZELWOOD MAGAZINE. v. 7. n. 2. March 1829, p. 21). Teachers and pupils took up a charitable subscription "by a consideration that the cause of the Greeks is independent of party feelings, and from a desire to follow the noble example set by the University of Cambridge." The total amount raised eventually reached $£ 64-6-1$, which was duly sent to John Bowring for use of the Greek Committee (HAZELWOOD MAGAZINE. v. 2. n. 5. June 1824, pp. 35-36; HAZELWOOD MAGAZINE. v. 2. n. 6. August 1824, pp. 40-41). Bowring was planning to sponsor additional Greek boys to come 
Hazelwood for a patriotic education, hinting at the need for special consideration because they were being educated with public funds on behalf of "the cause of which they are here in some measure as representatives" (BOWRING, 22 October 1824).

The Hazelwood Magazine, like the school's patrons and headmasters, also took a special interest in liberal and patriotic battles going on in Spanish America in the 1820s. Frederic Hill made an impassioned speech concerning the affairs of South America in the annual prize ceremony held in September 1827. In one issue the newsboys proudly announced the arrival of three Spanish Americans who were "the sons of officers in the patriot army, who fell in some of the engagements which have lately taken place in South America, whilst endeavouring to free themselves and their country from tyranny and oppression" (HAZELWOOD MAGAZINE. v. 4, n. 2. March 1826, p. 16). The Spanish American boys themselves took up their pens to publicize their cause in the pages of the school newspaper, blending classical rhetorical styles with impassioned cries on behalf of their fellow citizens. A typical one is "An Address to the Sun, written in the Spring, by a South American" which has the young boy looking at the clear blue sky (the color of the new flag of Argentina) and ends with the lines:

To think of the sweet, the wild shore of my birth, Oh change in thy course forcing nature's decree; And spread o'er La Plata thy lustre and mirth Though freezing with cold, I still happy shall be To think that thy care is the land of my birth

(HAZELWOOD MAGAZINE. v. 7, n. 9. November 1829, pp. 163-164).

In another example, a boy from Buenos Aires wrote a proclamation to document the progress he had made in learning English language in two years. It opened boldly: "ADDRESS TO SPAIN: .... Spaniards, awake! To Arms! The time of feedom [sic] is arrived and the shade of brave Riego calls for vengeance. Go and confound with your presence the trembling tyrants whose hearts already are filled with panic: go and shew gloomy fanaticism that you are no longer slaves, that you are again free men ... May the blessings of heaven and earth fall upon thy noble head and enrich thy sons with peace and union" (HAZELWOOD MAGAZINE. v. 5, n. 2. March 1827, pp. 26-27).

Another article written by an Argentine boy served a similar purpose. Juan Francisco Gil, the chargé d'affaires of the Argentine Republic in London, requested the work to see what progress "the essayist had made in English composition." The boy's opening lines alone should have been enough to convince him that the tuition costs had been money well spent. It began: "Allow me to congratulate you upon an event which sheds such lustre and dignity upon the council and arms of my native country. The battle of Ituzaingó shows that the same heaven-born spirit of liberty which roused my countrymen in former days to shake off the galling fetters of Spanish tyranny, still reigns unabated in their breasts ... The proud, ambitious Don Pedro [I of Brazil] has been baffled in his attempt to enslave us. ... A few years ago, nearly the whole of the vast continent of South America, was governed by the hand of a single individual, but now liberty reigns from Cape Horn to Terra Firme, and not a single foot of earth in this vast extent acknowledges him as its lord" (HAZELWOOD MAGAZINE v. 5. n. 5. August 1827, pp. 77-81). Just as the Hazelwood Magazine had given the sons of Greek patriots a public voice, it did the same for their classmates from Spanish America.

William Watson was an active boy editor and close friend of young Ecuadorean Vicente Rocafuerte and Argentine Antonio Rodriguez. He shared their youthful enthusiasm for liberty and battle cries with a composition called "South American Patriot's War Song", which includes the stanzas:

Arm for your country, republic and laws Arm for your freedom in liberty's cause Dash to the ground vile servility's chain Down with the tyrant, the despot of Spain. ... Freemen awake; 'tis the hour to be brave; Fight them, to die or to conquer and save. Flock to the standard that soareth on high, Freedom or death be the patriots' cry!

(HAZELWOOD MAGAZINE. v. 6, n. 3. April 1828, pp. 43-45). 
The title and the theme are both very similar to a work called "Spanish Patriot's Song" which was published in Thomas Campbell's popular New Monthly Magazine in 1823 as the French had just helped Ferdinand VII and Spanish reactionaries end the second liberal constitutional period. The refrain of this song urges readers to "Follow, follow / Shake the Spanish blade and sing / France shall ne'ever enslave us / Tyrants shall now brave us" (CAMPBELL, (1823), p. 491). Campbell had visited Hazelwood in 1821 and been so impressed that he sent his own young son there for education. Although this specific patriotic song referred to the Peninsular War and the struggle against Napoleon specifically, the strong sentiment of opposition to tyranny and foreign occupation was consistent across the transatlantic liberal revolutions of the 1810 s and 1820 s. $^{8}$

Matthew Davenport Hill wrote that "[t]he first object of an education should be, we think to render the after-life of the pupil most useful to society and most happy to himself; the next should be to render the passing years of the pupil as happy as possible." The Hazelwood Magazine put into practice many of the pedagogical and civic goals of the school's founders, including the desire to mold citizens of good character, to incorporate literacy and persuasion into rational leadership, and also explicitly, to help informed writers "gain ascendancy over the minds of others" (HILL, 1825, pp. 293, 324). The newsboy editors even quoted Arthur Hill in its their pages: "The system was meant not to play, but to work; to rear men and not children and to prepare boys, not for the nursery, but for the great world" (HAZELWOOD MAGAZINE. v. 5. n. 8. October 1827, p. 118). That was exactly the way the progressive study body of Hazelwood School saw themselves, as patriotic citizens of a universal liberal revolution, fighting against tyrants using their brains, their pens, and their fellowship. As Hannah Barker observed, there was" a belief in $19^{\text {th }}$ century England that it was possible for people to take an interest in public affairs and to offer commentary and critiques without challenging the overall social order" (BARKER, 1998, pp. 3-4). That condition was, of course, a necessary component of any participatory political system in which both stability and free speech are core values. In their studies at Hazelwood School, and especially through their participation in the production of the monthly Hazelwood Magazine, Spanish American newsboys had a practical introduction to the power that comes with access to the press, pedagogical reform and a patriotic desire to serve their new nations in a future waiting to be written.

\section{References}

ALONSO PIÑEIRO, Armando. Origines de la libertad de la prensa en la Argentina. Buenos Aires: Academia Nacional de Periodismo, 2004.

BANTMAN, Constance and DA SILVA, Ana Cláudia Suriani (ed.). The Foreign Political Press in Nineteenth-Century London: Politics from a Distance. London: Bloomsbury, 2018.

BARKER, Hannah. Newspaper Politics and Public Opinion in Eighteenth Century England. Oxford: Clarendon Press, 1998. https://doi.org/10.1093/acprof:oso/9780198207412.001.0001.

BARTRIP, P. W. J. 'A Thoroughly Good School': An Examination of the Hazelwood Experiment in Progressive Education: British Journal of Educational Studies, Oxford, GB, v. 28, n. 1, p. 45-59, Feb. 1980. https://doi.org/10.1 080/00071005.1980.9973560.

BOWRING, John. Messrs. Hill and Sons Sons. Greek Committee Room, London, 22 October 1824. Bruce Castle Archive, Hill Family Papers.

BROWN, Matthew; PAQUETTE, Gabriel, (ed.). Connections after Colonialism. Europe and Latin America in the 1820s. Tuscaloosa: University of Alabama Press, 2013.

BRUCE CASTLE ARCHIVE, Hill Family Manuscripts

CAMPBELL, Thomas. Spanish Patriots' Song. New Monthly Magazine, [s. l.], v. 7. 1823

CROPPER, James. A Letter Addressed to the Liverpool Society for Promoting the Abolition of Slavery. Liverpool: James Smith, 1823

CURRY, Kenneth. Sir Walter Scott and the Edinburgh Annual Register. Knoxville: University of Tennessee Press, 1977.

\footnotetext{
8 Good recent studies of this literary and historical phenomenon can be found in: SAGLIA and HAYWOOD, eds., 2017; BROWN and PAQUETTE, 2013: MUÑOZ and ALONSO GARCIA, eds., 2011.
} 
DA SILVA, Ana Cláudia Suriani; ABREU, Marcia (ed). The Cultural Revolution of the Nineteenth Century. Theatre, the Book-Trade and Reading in the Transatlantic World. London: I. B. Tauris, 2016

Despedida de las chilenas al egército libertador del Perú. Santiago de Chile: 1820. John Carter Brown Library bB820 D368d.

Despedida de las coquimbanas al egército libertador del Perú. Santiago de Chile: 1820. John Carter Brown Library bB820 D368C.

DOBSON, J. L. Hazelwood School: The Achievements of Rowland Hill and his Brother. Durham Research Review, London, v. 3-4, n. 11. p. 1-11, Sept. 1960.

DOBSON, J. L. Thomas Wright Hill and the School in Hill Top, Birmingham: Durham Research Review, London, v. 1-2, n. 10. p. 261-271, 1959.

DURÁN DE PORRAS, Elias. Galicia, The Times y la Guerra de la Independencia. Henry Crabb Robinson y la corresponsalia de The Times en A Coruña, 1808-1809. A Coruña: Fundación Pedro Barrié de la Maza, 2008.

FETTER, Frank W. The Economic Articles in the 'Westminster Review' and their Authors, 1824-1851: Journal of Political Economy, Chicago, v. 70, n. 6. p. 570-596, Dec. 1962. https://doi.org/10.1086/258717.

GOOD, H. G. Early Examples of Student Self-Government. Educational Research Bulletin, Columbus, Ohio, v. 24, n. 5, p. 113-118, May 1945.

\section{HAZELWOOD MAGAZINE. 1823-1829.}

HIGGINS, David Minden. Romantic Genius and the Literary Magazine. Biography, Celebrity and Politics. London and New York: Routledge, 2005.

HILL, Matthew Davenport. Public Education: Plans for the Government and Liberal Instruction of Boys in Large Numbers; as Practised at Hazelwood School. London: C. Knight, 1825.

HILL, Thomas Wright. Jeremy Bentham. Hazelwood, near Birmingham, 8 March 1824. University College London, Special Collections, Jeremy Bentham Manuscripts, box 10, f. 146.

HILL, Thomas Wright. Jeremy Bentham. Hazelwood, 18 August 1824. In: O'SULLIVAN, Luke; FULLER, Catherine, (ed.). The Correspondence of Jeremy Bentham. Oxford: Clarendon Press, 2006. v. 12, p. 16-17. https:// doi.org/10.1093/oseo/instance.00067417.

HORACE. The Works of Horace, Translated into English Prose ... for the use of Schools as well as Private Gentlemen. London: [s. n.], 1753

LANGFORD, Paul. Englishness Identified. Manners and Character, 1650-1850. Oxford: Oxford University Press, 2000.

LLORENS, Vicente. Colaboraciones de emigrados españoles en revistas inglesas 1824-1834. Hispanic Review, Philadelphia, v. 19, n. 2. p. 121-142, Apr. 1951. https://doi.org/10.2307/470940.

LUSTOSA, Isabel. Insultos impressos. A guerra dos jornalistas na Independência, 1821-1823. Rio de Janeiro: Companhia das Letras, 2000.
MUÑOZ SEMPERE, Daniel; ALONSO GARCÍA, Gregorio (ed.). Londres y el liberalismo hispánico. Madrid and Frankfurt: Vervuert. 2011. https://doi. org/10.31819/9783954879137.

NORTH, Julian. The Domestication of Genius. Biography and the Romantic Poet. Oxford: Oxford University Press, 2009. https://doi.org/10.1093/acprof:oso/9780199571987.003.0003.

PERRIN, Andrew J. 'Since this is the editorial section I intend to express my opinion': Inequality and Expressivity in Letters to the Editor. The Communication Review, [s. l.], v. 19, n. 1, 55-76, 2016. https://doi.org/10.1080/10 714421.2016.1128188.

RACINE, Karen. Patriots-in-Training: Spanish American Children at Hazelwood School near. Birmingham, England in the 1820s. Paedagogica Historica, Gent, Belgica, BE, v. 46, n. 4, p. 495-509, 2020. https://doi.or g/10.1080/00309230.2010.493163.

ROLDÁN VERA, Eugenia; CARUSO, Marcelo (ed). Imported Modernity in Post-Colonial State Formation. The Appropriation of Political, Educational, and Cultural Models in Nineteenth-Century Latin America. Frankfurt am Main: Peter Lang, 2007.

ROLDÁN VERA, Eugenia. The British Book Trade and Spanish American Independence. Education and Knowledge Transmission in Transcontinental Perspective. New York: Routledge, 2003.

SAGLIA, Diego; HAYWOOD, Ian (ed.). Spain in British Romanticism, 1800-1850. London: Palgrave Macmillan, 2017. https://doi.org/10.1007/978-3-319-64456-1.

SAGLIA, Diego. Hispanism in 'The New Monthly Magazine', 1821-1825. Notes and Queries, London, v. 49, n. 1, p. 49-55, Mar. 2002. https://doi.org/10.1093/nq/49.1.49.

SNYDER, Carey; SORENSON, Leif. Letters to the Editor as a Serial Form. The Journal of Modern Periodical Studies, [S. l.J, v. 9. n. 1, p. 123-146, 2018. https://doi. org/10.5325/jmodeperistud.9.1.0123.

STEWART, David. 'We are Absolutely Coining Money': Commerce, Literature and the Magazine Style of the 1810 s and 1820 s. Nineteenth Century Contexts, IS. l.], v. 39, n. 1, p. 21-37, Mar. 2008. https://doi. org/10.1080/08905490801945512.

TODD, David. John Bowring and the Global Dissemination of Free Trade: The Historical Journal, London, v. 51, n. 2, p. 373-397, June 2008. https://doi.org/10.1017/ S0018246X08006754.

UNIVERSITY COLLEGE LONDON. Special Collections. Jeremy Bentham Manuscripts 18/179.

VALENCIA, Miguel. Juan Francisco Gil. Hazelwood School, 17 December 1827. Archivo General de la Nación-Argentina, Documentos Escritos, Sala X 1-1-12.

VIRGIL. The Works of Virgil, translated into English Prose... for use in Schools. London: [s. n.], 1821.

WILLIAMS, Kevin. Read All About It- A History of the British Newspaper. London: New York: Routledge, 2010. https://doi.org/10.4324/9780203596890. 
Mailing address

Karen Racine

University of Guelph, Stone Road

Guelph N1G 2W1

Ontario, Canada 